\title{
Artelogie
}

artelogie Recherche sur les arts, le patrimoine et la littérature de l'Amérique latine

13 | 2019

Violeta Parra: authenticité, primitivisme et processus d'exotisme chez les artistes latino-américains.

\section{Interculturalidad y proyectos alternativos en Violeta Parra: su encuentro con el canto mapuche}

Prof. Paula Miranda Herrera.

\section{(2) OpenEdition \\ Journals}

Edición electrónica

URL: http://journals.openedition.org/artelogie/2794

DOI: 10.4000/artelogie.2794

ISSN: 2115-6395

Editor

Association ESCAL

Referencia electrónica

Prof. Paula Miranda Herrera., «Interculturalidad y proyectos alternativos en Violeta Parra: su encuentro con el canto mapuche », Artelogie [En línea], 13 | 2019, Publicado el 07 septiembre 2018 consultado el 20 abril 2019. URL : http://journals.openedition.org/artelogie/2794 ; DOI : 10.4000/ artelogie.2794

Este documento fue generado automáticamente el 20 abril 2019.

Association ESCAL 


\title{
Interculturalidad y proyectos alternativos en Violeta Parra: su encuentro con el canto mapuche
}

\author{
Prof. Paula Miranda Herrera.
}

1 Avanzar hacia la formación de una sociedad intercultural implica la construcción de relaciones e interacciones entre personas de diversos orígenes culturales en base al respeto y valoración de esta diversidad, y de la promoción de espacios igualitarios y de reconocimiento, donde la diferencia sea percibida como un valor y una riqueza para la sociedad y no como una barrera. Sin embargo, en la realidad, esos espacios para el encuentro entre dos culturas no siempre han sido posibles ni su promoción ha estado exenta de tensiones, colonialismos y violencia simbólica. Durante gran parte del siglo XX chileno, el Estado nacional chileno tendió a no reconocer su realidad pluricultural y favoreció en general políticas y campañas integracionistas de "chilenización", que buscaban integrar, homogeneizándolos, tanto a los inmigrantes como a los distintos pueblos indígenas del país ${ }^{1}$. Guillaume Boccara afirma que solo en los últimos veinte años, el Estado chileno se ha autoasumido como una "entidad pluricultural y multiétnica" (BOCCARA, 2012:p.14), aunque siga sin reconocer la necesidad de la autonomía como base para una nueva relación entre el Estado y los pueblos indígenas ${ }^{2}$.

2 Sin embargo y a contrapelo de estas políticas integracionistas, algunas prácticas artísticas del siglo XX chileno reclamaron la urgencia del reconocimiento intercultural a través de sus obras y de sus proyectos, promoviendo indirectamente la descolonización de los saberes y de las relaciones sociales desde lo artístico. Lo que aquí me interesa relevar es que entre los artistas que trabajaron tenazmente en esta línea, destacó singularmente el proyecto y la obra de Violeta Parra, quien esgrimió sus propuestas estéticas y culturales con clara intención intercultural y a la vez descolonizadora. Aquí revisaremos parte de esa labor y especialmente su inmersión investigativa y vital en la cultura mapuche, aspecto muy poco abordado en los estudios anteriores a mi libro Violeta Parra en el Wallmapu. Su encuentro con el pueblo mapuche (2017), del cual atraeré aquí algunas de sus conclusiones más relevantes. 


\section{1-. Proyecto alternativo e intercultural}

3 A contrapelo de las versiones folklóricas oficiales que se difundían en el Chile de los años 50, Violeta Parra recorrió desde 1952 gran parte de nuestro país para reconstruir un mapa alternativo, cultural y acústico, que recogiese todo lo que éramos y habíamos sido como país, que considerase los diversos registros poético-musicales que conformaban Chile: de norte a sur, de mar a cordillera, incluyendo Rapa Nui. El mapa le serviría para llevar a cabo un proyecto mayor: revitalizar la cultura popular tradicional de Chile y revelar su pluriculturalidad, negada sucesivamente por las versiones oficiales de la chilenidad. Eso lo lograría a través de la recopilación y la difusión del folklore, entendido como "el canto de todos" (PARRA.V, 2016: p.139). Pese a que en Chile existían instituciones, investigadores y artistas que también estaban realizando labores de recolección similares, incluso en el ámbito del canto mapuche, el hecho de que fuese Violeta Parra quien lo hiciese, cobra hoy especiales sentidos y alcances para esas recopilaciones y para la música en general, por el alto impacto que tendrá su arte, sobre todo de creación, a nivel continental y mundial, a partir de los años 70 y por la difusión-proyección atípica que ella hará de cada uno de estos patrimonios. Parra se convertirá al correr de los años en la folklorista más experimental y en la vanguardista más tradicional de nuestra música y de nuestra poesía; capaz de preservar y reelaborar los cantos y creaciones de diversas culturas, aportando así al conocimiento del otro y a la valoración del diálogo intercultural. Su obra es por eso mucho más que una obra: es un proyecto intercultural, un puente entre culturas.

4 Antes de recopilar el canto mapuche, y también simultáneamente, Violeta recopila cientos de piezas de la tradición, de manos de "cantores auténticos" de distintos géneros y a lo largo de todo el país. Para hacerlo, demuestra un gran poder de seducción, cercanía y empatía respecto de quienes entrevista y evidencia a la vez un genuino interés por lo que ellos le puedan entregar. En su poema "Defensa de Violeta Parra", su hermano mayor Nicanor Parra, destaca esta ardua labor de investigación y difusión que su hermana comenzó a realizar en 1952 y que no se detuvo nunca. Las imágenes sostenidas en versos de sáfica adónica, nos muestran a una Violeta recorriendo un lugar unido por lazos fraternos, geográficos e históricos y realizando allí dos acciones vitales para la pervivencia de esa comunidad: desenterrar "cántaros de greda" y liberar "pájaros cautivos" (PARRA.N, 1969: p.219). Los cántaros son concretamente vasijas tradicionales de la alfarería chilena (que a Violeta le preocupó rescatar), pero la palabra también contiene los fonemas de cantos y cantores. El sentido más acertado de Nicanor se concentra en su última imagen: "liberando pájaros cautivos/ entre las ramas" (PARRA.N, 1969: p.219): todo el canto enterrado y prisionero, podrá finalmente ser liberado a partir de su acción de rescate. Sentido reforzado en otra imagen de la "Defensa...": “Árbol lleno de pájaros cantores" (PARRA.N, 1969: p.219), donde Violeta se convertirá en un ente nutricio colmado de esos pájaros que ella misma ha liberado.

5 Un poco menos de la mitad del total de su repertorio corresponde a canciones de recopilación, el que ella difundió bajo su personal interpretación, especialmente a partir de 1960 en diversos discos y también en dos libros. Cada una de estas obras de difusión, especialmente los seis volúmenes de El folklore de Chile, coincidió además con un determinado momento estético y vital: lo recopilado la comprometía siempre vitalmente, no era una coleccionista de objetos, sino alguien que encontraba en esos cantos algo que 
le concernía profundamente: como mujer, como sujeto social, como artista, como "poeta de la música", como chilena. Por ello su arte debe ser entendida en una doble vertiente creativa: la de sus composiciones originales y la de la recreación e interpretación de piezas de la tradición. Ambos quehaceres son un acto de creación (poiesis), aunque sólo uno produzca temas originales y, el otro, canciones reapropiadas.

El registro de su labor de recopilación quedó consignado en varias cintas y cuadernos de recopilación, algunos de los cuales han sido difundidos, aunque queden varios por ser conocidos. Parte de esta labor se publicó en sus dos libros: en Poésie populaire des Andes (publicado en París en 1965) y en Cantos folklóricos chilenos (ideado en 1959 y publicado póstumamente en 1979). También en diecisiete singles y en sus LP: El folklore de Chile (seis volúmenes editados entre 1956 y 1958), Chants et danses du Chili (dos volúmenes de 1956), Cantos de Chile (1956) y El folklore según Violeta Parra (1962). Además, difundió lo encontrado de manera atípica al realizar programas radiales y proyectos, como la creación del Museo de Arte Popular y Folklórico en Concepción y el de la Carpa de la Reina, inaugurados en enero de 1958 y en diciembre de 1965, respectivamente. En esas acciones Violeta recopiló y difundió importantes géneros de la canción tradicional chilena, especialmente: el canto a lo poeta (en sus vertientes de canto a lo divino, a lo humano y de paya), la cueca, la sirilla, el vals y la tonada. La característica esencial de esta labor, es que todo impactó de manera determinante en su obra de creación y que los diversos elementos y expresiones de estas culturas se resolvieron en su obra desde una resuelta movilidad fronteriza y de hibridación.

7 Sin embargo, y hasta hace unos cuantos años atrás, muy pocas personas en Chile reconocían que parte importante de ese diálogo intercultural e intertextual, tan determinante para la poética de Violeta Parra, se había nutrido de la cultura mapuche. Entre esas decenas de cintas en que registró cantos tradicionales, encontré el año 2014, cuatro cintas con ochenta minutos de grabación, catalogadas y digitalizadas ${ }^{3}$, en las que Violeta Parra entrevista a un ülkantufe (cantor), a seis cantoras mapuche ${ }^{4}$ y recopila treinta y nueve cantos en mapuzugun interpretados por sus propios cultores. En ese trabajo, que permaneció ignorado desde el año 1958, en todos los estudios, menciones y ediciones o re-ediciones de su obra, encontramos aquel eslabón que la conecta con el mundo mapuche, en el mismo nivel de influencia fundamental que ella recibió de la cueca, la tonada, el canto a lo poeta o la sirilla. Influencia que se hizo notar en su rigurosa investigación y recopilación sistemática de esos géneros. Así, podemos afirmar hoy con absoluta seguridad, que una de las artistas más admiradas en Chile y el mundo, por su capacidad para interpelar nuestras emociones, visiones y experiencias, también nutrió su obra de la cultura mapuche. Es más, por las fechas en que esas grabaciones fueron realizadas (1957-1958), es probable que esa conexión contribuyese a gatillar en ella el despliegue de su etapa más creativa y experimental, bajo una impronta única y radical, comenzando con "El Gavilán", las anticuecas y sus décimas autobiográficas.

Constatar esta presencia fundamental en la obra de alguien como Violeta Parra, permite demostrar que las culturas, lengua y visiones mapuche, han estado presentes en la cultura chilena mucho más poderosamente de lo que muchos están (o estaban) dispuestos a reconocer. Quien admire su obra, admira también la rica diversidad y raíces de las que estamos constituidos, reconoce en todo chileno, esa hermosa morenidad ${ }^{5}$ de la que habla el poeta mapuche Elicura Chihuailaf y sin la cual Chile no sería lo que es hoy, enriquecido con la belleza de las músicas, palabras, medicinas, lengua, emociones y sueños del territorio mapuche o Wallmapu. Este encuentro influirá a nivel temático, poético y 
musical en las canciones, en el arte visual y también en los proyectos de Violeta Parra; pero sobre todo en su comprensión del mundo y en el sentido que adquirirá su arte: en función social y comunitaria ${ }^{6}$. La machi María Painen Cotaro, a quien Violeta visita en su ruka (casa) diariamente durante más de un mes en 1957, la introducirá en la cultura mapuche con sus enseñanzas y le ayudará a construir su propia autoimagen: la de una mujer poderosa que podrá sanar a otros y aliviar sus propios dolores a través del canto, de la palabgra. De esa condición pluricultural que poseen nuestros países, es de lo que nos vino a hablar Violeta Parra. De esa hermandad en el canto, es de lo que ella nos hablará en su proyecto. De ahí su labor y ejemplo pioneros: "en su divina comprensión, luces brotaban del cantor" (PARRA.V, 2016: p.44), nos dirá en su canción "Cantores que reflexionan" el año 1966.

Antes de describir los hitos fundamentales de este encuentro, me interesa describir el contexto en el que esa labor tuvo lugar, en el plano de la naturaleza de su trabajo de investigación etnográfica.

\section{2-. Su atípica labor de recopilación y difusión}

10 Su obra de recopilación y de creación, impactó con inusitada fuerza la tradición de la poesía popular chilena, del folklore y de la música en general, y la razón fundamental de ello radica en que Violeta fue capaz de escuchar, reapropiarse y potenciar en sus proyectos culturales y en su obra las influencias de la cultura popular chilena, portadora de un diálogo intercultural, tenso y complejo, de varios siglos. Sin embargo, lo hizo de una manera muy distinta a la de recopiladores o estudiosos chilenos, anteriores o contemporáneos, lo que no puede obviar la extensa trayectoria que había tenido la investigación musicológica en el ámbito del folklore chileno y que logró marcar desde fines del siglo XIX dos tendencias: la hispanista y la indigenista. Labor que iniciaron Rodolfo Lenz y Julio Vicuña Cifuentes con la fundación de la Sociedad de Folklore Chileno en 1909 y que tuvo su continuidad, en su vertiente indigenista, por Carlos Lavín, Oreste Plath y Eugenio Pereira Salas.

11 Entre los que se inscriben en la vertiente indigenista y que aportaron obras significativas a la integración y/o difusión de la música mapuche están Carlos Lavín, recolector de canto mapuche, y Carlos Isamitt, quien recopila también canto mapuche y además compone piezas musicales basadas en ese legado. Ambos desarrollaron desde los años 40, una labor fundamental, junto a otros investigadores y colaboradores del Instituto de Investigaciones de Música Tradicional de Chile, de la Universidad de Chile. Sin embargo, para Víctor Rendón, esta doble mirada, algo esquemática y descontextualizada respecto de los cambios históricos, no varió en los años 60 , pese al giro epistémico que hubo en la antropología: "Ni aún después de los años 60, con la irrupción de la etnomusicología en nuestro medio académico, esta situación varió y los estudios en música de tradición oral siguió la misma dicotomía" (RENDÓN, 2000: p.9). Aportes fundamentales realizaron investigadores como María Ester Grebe y Manuel Dannemann, pero ellos no variaron las epistemologías del trabajo de campo. Para los años en que Violeta Parra realiza su labor, algo parecido están haciendo entonces otros músicos y folklorólogos, como Margot Loyola, a quien Violeta conoce a inicios de los años 50, pero quien había comenzado en la década de los 40 a recopilar el folklore no oficial de Chile. 
12 Pero el rasgo distintivo de Violeta en este ámbito fue trazado por José María Arguedas en el Congreso homenaje a Violeta Parra que tuvo lugar en la Universidad de Chile, a un año de su trágica muerte. Allí, el escritor y antropólogo peruano aseveró:

Al identificarse y crear sobre manifestaciones folklóricas caracterizantes de clases sociales o de razas (a las cuales se las considera inferiores porque por el hecho de haber estado marginadas, esas razas mantienen al mismo tiempo características distintas), la artista realiza el milagro de lanzar estos elementos diferenciantes y segregantes, como un elemento unificador, universalizador, y no solamente en el plano nacional (...). Ella es lo más chileno de lo más chileno que yo tenga la posibilidad de sentir; sin embargo, es, al mismo tiempo, lo más universal que he conocido en Chile. (ARGUEDAS, 1968: p.71)

Esa diferencia no radicaría en el hecho de ser chilena como un valor en sí mismo, sino que provendría justamente de aquellos saberes y manifestaciones que esa cultura nacional ha subalternizado y subvalorado sistemáticamente, especialmente las indígenas. Lo que Violeta veía en todas esas expresiones era su diferencia, la riqueza de su sentido único e irrepetible. De hecho, en la cultura popular cada género poético o musical adquiere muchas formas de actualización, dependiendo de la localidad o de la situación en la que se produzca. Chile es un país hecho de fragmentos debido a su geografía muy angosta y extensa, lo que crea muchas situaciones de aislamiento e incomunicación entre distintas zonas. Así, un mismo género adquirirá melodías bastantes diferentes en diversas zonas, lo que hace que los tonos y los temples e incluso las poéticas de cada cantor sean de una enorme variedad y de una amplísima posibilidad de registros, siempre dentro de un mismo género. Justamente de esa enorme amalgama tomará Violeta no sólo temas, motivos y formatos, sino también tonos y registros, instrumentaciones y motivos. De la cueca (baile oficial nacional), por ejemplo, existen diversas modalidades dependiendo de la zona geográfica en que se cultive: cueca nortina, chilota, porteña, valseada, chora, etc. De ahí también la forma muy particular que tuvo Violeta de preservar esas expresiones, pues una de sus máximas era la obtener la mayor cantidad de veriones y diversificaciones de distintos géneros. Para lograrlo, ella averiguaba rigurosamente dónde podría encontrar cantores "viejitos" y "auténticos" (como ella misma les llamaba) y una vez que lo lograba, los conocía de cerca, conversaba y compartía con ellos sus saberes, costumbres y creencias, sus dichos y expresiones, sus cantos y versos, los sub-géneros de esos cantos, sus formas musicales. En ese proceso creaba vínculos de amistad, pues a muchos lugares ella retornaba en varias ocasiones. Una de sus estrategias era partir ella misma cantando, para luego invitarlos a ellos a cantar y siempre les retribuía con algún presente, aunque a veces fuese solo con su propio canto. "Si a mí no hay que tenerme vergüenza, yo soy cantora también"7 (PARRA.V, 1958: s/p), le dice en Lautaro al ülkantufe Juan López Quilapán, cuando este se muestra algo tímido frente a la petición que ella ha hecho de los cantos.

Es distinta también la forma en que Violeta valora esos cantos, pues ella descubre en esos cantores y cantoras no sólo textos, sino sobre todo elementos que le ayudarán a ella misma a construir su imagen: modos de hablar, de ser, de pensar, de erigirse como sujeto autónomo y sobre todo de cantar. Los giros, el humor, la desinhibición, la sabiduría acumulada, el repentismo, la pasión carnal de las cantoras de tonadas, la fina y delicada cultura que observa en ellos, la ritualidad y espiritualidad del canto a lo divino (Isaías Angulo) y del canto de machi (María Painen Cotaro), es lo que marcará para siempre todos sus quehaceres y toda su obra de creación. En este sentido, a Violeta no sólo le interesa el objeto que va a rescatar, sino que incorpora los procedimientos y técnicas de esos y esas 
cultoras a su propia obra. Recompone además en algunos casos fragmento a fragmento algunas piezas folklóricas, con cuidado y precisión. Lo que estos cantores le regalan así a Violeta es algo mucho más valioso: le ofrecen la manera en que ella deberá revitalizar la tradición desde su propio arte y el sentido que deberá tener su propia creación. De ellos, Violeta aprende destrezas que ningún investigador había notado en esta poesía, pues lo que ellos recopilaban eran objetos y no personas. De esa manera, Violeta supera ampliamente la labor etnográfica y antropológica, otorgándole a ambas nuevo status y nuevos desafíos metodológicos. No conozco en esta línea trabajos similares, sí probablemente de parte de artistas, como Margot Loyola, Gabriela Pizarro, Rolando Alarcón o el mismo Víctor Jara; aunque todos con matices y alcances muy diversos.

Parra dedica los primeros años a la investigación de la tradición folklórica de la Provincia de Ñuble, especialmente en torno a las cantoras de tonadas y muy especialmente del canto a lo poeta (a lo divino, a lo humano y paya). Luego amplía su campo de acción hacia el norte chico de Chile (Vicuña) y hacia la zona central (entre Ovalle y Maule), concentrándose de manera especial en el canto a lo poeta y en la cueca. Luego hacia el sur de Chile (1957-1958), con especial atención en Concepción (en la región del Bío Bío) y en la región de la Araucanía, especialmente en Lautaro y Freire, lugares donde conocerá y se deslumbrará con el ülkantun mapuche. En los últimos años de labor, se sumerge en los ritmos de la Isla de Chiloé (valses, sirillas, periconas), algunos de raíz huilliche y en algunas piezas del folklore nortino: "ella grabó en cinta magnética los cantos de la Fiesta de la Tirana y, aparte de esto, tuvo contacto con muchos cantores pampinos y les grabó sus repertorios" (SUBERCASEUX, 1982:p. 48), testimonia Gastón Soublette, quien en muchos casos le transcribió en pauta la música de aquellos repertorios, pues ella no escribía música.

17 Toda esta labor la realizó con muy poco apoyo institucional " "miseria y padecimiento me dan los versos que encuentro" (PARRA.V, 1970:p.25), le dice a Nicanor Parra en sus Décimas autobiográficas (1970), aunque tiene contacto esporádico con importantes Universidades: es contratada por la Universidad de Concepción entre 1957 y 1958 para recopilar patrimonio folklórico de la zona y dictar clases en escuelas de temporada en la ciudad; es colaboradora y dona material importante al Instituto de Investigaciones de Música Tradicional de Chile de la Universidad de Chile, en 1958; y es contratada puntualmente por la Universidad Católica del Norte, en 1959, para "ofrecer unas clases de folclore" (PARRA. I, 2009: p. 108) ${ }^{8}$. Su vínculo más importante es sin duda el que mantiene con la Universidad de Concepción, donde el rector David Stitchkin la contrata para realizar labores de recopilación y estudio del folklore en la zona, especialmente de cantos y costumbres, por mediación de Gonzalo Rojas (poeta y gestor de extensión en esa Universidad). La Universidad de Concepción vivía un radical proceso de reforma universitaria y fue la primera institución de investigación que abrió sus puertas a la folklorista, valorándola como formadora al llamarla "profesora" y "conferencista" . Es un momento en que Violeta Parra se siente reconocida y apoyada de manera institucional, sirviendo esto de gran estímulo para su labor investigativa y creativa. En su trabajo de investigación en Concepción, Violeta comenzó por Hualqui y terminó fundando, por propia iniciativa y con el apoyo de la Universidad, el Museo de Arte Popular y Folklórico en Concepción, en enero del año 1958. Se asombró ella con la gran cantidad de gramófonos e instrumentos antiguos que encontró en la zona (arpas, guitarrones, charangos, cultrunes, panderetas), pero también con los cancioneros tradicionales, con la cultura mapuche y con las alfarerías tradicionales, como la de Quinchamalí. Conoció allí 
además a numerosos artistas, pintores, músicos y escritores. Todo lo cual impactará de manera determinante en sus quehaceres a partir de 1957.

La difusión la hará a través de discos, programas radiales o conferencias universitarias. A medida que Violeta recopila, irá haciendo una rigurosa selección del material para grabar algunas de esas piezas bajo su personal interpretación, agregándoles su propia puesta en escena y vivacidad. A inicios de los años 50 ella prefiere el folklore a sus propias composiciones (todavía escasas), y del mismo ofrece el siguiente testimonio: "amo y venero el canto a lo humano y a lo divino desde el punto de vista del texto literario y del punto de vista musical" ${ }^{10}$ (PARRA.V, 2010: $\mathrm{s} / \mathrm{p}$ ). Pero para que esta labor cobrara su pleno sentido, era necesario que el público chileno estuviese comprometido con este proyecto, lo que lamentablemente no sucedía. Todavía en 1960 Violeta Parra se quejaba: "Me enojo con medio mundo para salir adelante, porque todavía ni la décima parte de los chilenos conoce su folklore, así es que tengo que estar batallando casi puerta por puerta, ventana por ventana. Es harto duro todavía, es como si estuviera empezando recién..." ${ }^{11}$ (PARRA.V, 2010: s/p). Hay un tono permanente de cansancio debido a la labor titánica que tiene que realizar y a la falta de comprensión por parte del público chileno. Entre todas las piezas poético-musicales que recopiló, especial interés tuvo en el ülkantun, canto ancestral del pueblo mapuche, pero que es el único que Violeta no difundió, debido a que sentía un profundo respeto por él y pensaba que "si, alguien debía dar a conocer esos cantos rituales, con el necesario respeto, tenía que ser un representante de ese pueblo" (PARRA. Á, 2006: p.118), según testimonia su hijo Ángel Parra.

\section{3-. Su encuentro con el canto mapuche}

19 Si bien algunos estudios reconocían que había sonoridades de la música mapuche en algunas de sus canciones, faltaba una prueba que nos permitiese asegurar que Violeta Parra se había relacionado con esa tradición de la manera que he descrito. Hace tres años, encontré esa prueba en la Universidad de Chile y con la colaboración imprescindible de mis colegas Elisa Loncon y Allison Ramay nos dimos a la tarea de reconstruir las historias que estaban detrás de las cintas redescubiertas, entrevistamos a distintos descendientes o amigos de los cantores y pudimos contextualizar su trabajo y valorar su impacto. En base a esto acabamos de publicar el año recién pasado por Pehuén Editores, el libro Violeta Parra en el Wallmapu. Su encuentro con el canto mapuche (2017). En lo que sigue, me centraré en el impacto que tuvo todo esto en su obra y en sus proyectos; para concluir por qué podríamos pensar en este trabajo como aquel en que mejor se expresó su interculturalidad alternativa.

\section{1-. Cuándo y cómo ocurre el encuentro}

En un determinado momento Violeta tuvo la certeza que en ese puzzle multicolor del folklore y la cultura popular que ella venía recopilando desde 1952, faltaba reconocer el aporte de la cultura mapuche. Este trabajo de investigación realizado por Violeta, que permaneció ignorado desde 1957 en todos los estudios y ediciones o re-ediciones de su obra $^{12}$, permite afirmar hoy con absoluta seguridad que ella nutrió su obra también de la cultura mapuche. Es más, por las fechas en que esas grabaciones fueron realizadas (1957-1958), es probable que esa conexión contribuyese a gatillar en ella el despliegue de 
su etapa más creativa y experimental, bajo una impronta única y radical, comenzando con "El Gavilán", las anticuecas y sus décimas autobiográficas.

Justamente debido a que nació y se crió en una zona de fronteras como son las regiones del Bío Bío (San Carlos, San Fabián de Alico, Chillán) y de la Araucanía (Lautaro) (1921-1927), Violeta asimiló entre los años 1917 y 1932, a través de sus padres, familiares y amigos cercanos, una cultura rica en festividades, rituales, comidas, cantos y bailes comunitarios y conoció todas las tradiciones musicales que ya he nombrado. Desde 1953 esto se convertiría en un trabajo sistemático de recopilación, estudio y difusión del folklore, que no se detendría sino hasta su muerte. Por eso en una carta inédita escrita por ella en París y dirigida a Paul Rivet, Director del Museo del Hombre, le dice en 1955: "Mi único deseo es trabajar, para poder continuar mi labor de difusión folklórica, que es cosa aparte del trabajo y tan importante como este". Hay en ella una permanente preocupación de difusión folklórica a través de la discografía (dieciocho discos contienen en su gran mayoría, cantos de la tradición reintepretados por ella), la radiofonía (programas radiales como "Canta Violeta Parra" o entrevistas), la educación (talleres de baile y guitarra en Concepción, Ginebra y en la Universidad del Norte o la misma Carpa de la Reina) y de su propia creación.

Para 1957 la Universidad de Concepción la había contratado para realizar trabajos de investigación etnomusicológica. Y es justamente en ese año que Violeta llega al Coro de profesores de Temuco preguntando por canto de machi. Un profesor, Hernán Herrera, la lleva a su casa en Millelche y allí la hospeda durante un mes. Durante ese mes, Violeta entrevista diariamente a la machi María Painen Cotaro y comparte desde las ocho de la mañana hasta las seis de la tarde, su ruka y el conocimiento ancestral de la sanación a través de las hierbas, el toque del kultrung y el canto ${ }^{13}$. Esa primera inmersión profunda y deslumbrada en la cultura mapuche, le permite al año siguiente, dejar grabadas las voces y testimonios, en la casa de Fernando Teillier (Lautaro), de Juan López Quilapan, Juanita Lepilaf, de Adela y Rosita. En Labranza, es probable que ese mismo año, haya dejado registradas las voces de las cantoras Carmela Colipi, Juana Huenuqueo y María Quiñenao. Según lo estableció Elisa Loncon, en el libro que mencioné más arriba, el contenido central de las cintas son treinta y nueve cantos en mapuzugun, de temáticas intracomunitarias y circunstanciales, de una profunda emotividad y fuerza expresiva, algunos improvisados, otros memorizados, algunos vinculados a rituales, la mayoría a tareas del diario vivir: enamorarse, trabajar en la trilla, hacer dormir la guagüita, enviudar, tomar decisiones. Aunque también aparecen cantos ligados al ngillatun y al machitun. A través de sus temáticas, de las voces, ritmos e inflexiones emotivas de los cantores, se aprecia la gran energía y especial creatividad del canto y la palabra mapuche.

Al recopilar estos cantos, Violeta interactúa profundamente con sus depositarios, por lo que su obra se nutre tanto de los cantos mismos como de lo que las personas le conversan y le enseñan a través de las conversaciones. Violeta intenciona el especial tipo de canto que recopila e indaga sobre cuándo son cantados: “¿Y cuándo se cantan?”, ¿para qué se cantan?", les pregunta insistentemente. Pero también les pregunta por lo esencial, por su mensaje: “¿Y qué dice la palabra?" (MIRANDA, 2017: p. 33). De esos cantos y de sus depositarios, ella obtendrá aprendizajes para su propia vida y para el sentido que irá adquiriendo su quehacer: capacidad de improvisación y de productividad idiomática; funcionalidad y síntesis poéticas; enorme importancia otorgada a la palabra, cantada o recitada; capacidad vital de subsistencia, resiliencia y adaptación; cierto humor; una 
comprensión desde la emocionalidad; apego y gratitud hacia la naturaleza; centralidad de la figura de la mujer e importancia de la familia, entre las más importantes.

Este sustrato cultural, poético y musical impactará en toda su creación, y no solo en las canciones más explícitas sobre el tema. Todos estos cantos tienden a las analogías, a un vínculo con los sonidos y sensaciones ligadas a la naturaleza: "Para olvidarme de ti voy a cultivar la tierra" (PARRA.V, 2016:p64.), había dicho ya antes en "La jardinera" en 1956. Pero lo más importante, hay en ellos una responsabilidad social: la de trasmutar el mundo en otra cosa. Esa palabra-acción permite a las comunidades hacer catarsis, sanaciones, rituales conmemorativos o chamánicos, actos cotidianos de reafirmación identitaria y de comunión. Por eso ella afirmará en "Cantores que reflexionan" del año 1966, la opción por un canto que "abre surcos" y de un cantor que le canta "al hombre en su dolor" y "en su motivo de existir" (PARRA.V, 2016:p44)

\section{2-. Poligrafías y proyectos}

Esta concepción también influirá en sus proyectos culturales, especialmente en el último que ella desarrolló en "La Carpa de la Reina" ${ }^{14}$ y también en su trabajo con las arpilleras. El sueño de Violeta era convertir ese lugar a largo plazo en una universidad del folklore. El lugar fue construido en base a una carpa de circo, pero reproducía la disposición del espacio esférico de la ruka y la centralidad del fogón; de él se sacaban pequeños braceritos que eran puestos en las mesas, multiplicando su calor. Esa imagen la adquirió en parte y sin duda de la visita que realizó Violeta a la ruka de la machi María Painen Cotaro, de quien aprendió lo más fundamental de esa cultura: su sentido espacial y culinario; su circularidad y la dimensión medicinal de la palabra, tanto del canto y del kultrung. Esa capacidad del fogón de multiplicar el calor para recibir a todos, se manifestó también en que Violeta invitó a "La Carpa..." a diversos grupos musicales folklóricos latinoamericanos, destacándose "Los Araucanos", grupo de Juan Lemuñir, y también el grupo "Huenchullán", además de Lautaro Manquilef y otros músicos mapuche, con quienes creó fuertes lazos de amistad.

Su arte plástico se verá también positivamente marcado por esta presencia, especialmente en sus arpilleras (más históricas) y en sus óleos (rituales). Viviana Hormazábal (2013) desarrolló una tesis en que el óleo "Machitún" y las arpilleras "Fresia y Caupolicán" y "Los conquistadores" fueron analizados iconográficamente, destacando su vínculo formal y de contenidos con el mundo mapuche, sobre todo a partir de la creación de personajes y situaciones, de la combinación de colores y simbologías, del uso de perspectiva plana y de la yuxtaposición de elementos, casi siguiendo la forma de la textilería y alfarería mapuche. Gran influencia tendrá esta poligrafía y concepción espiritual en sus arpilleras "Contra la guerra" y "El árbol de la vida". En todos estos trabajos, Violeta estuvo influida por las técnicas ancestrales del telar y tejido mapuche y andino; más que por las formas artísticas modernas.

\section{3-. Comunidad de mujeres}

Otra influencia determinante en este encuentro serán las imágenes de mujeres que Violeta conocerá en este nuevo contexto y que se suman a la extensa genealogía de figuras femeninas que le han servido en su propia autoimagen: la de su madre, de cantoras populares y de tonadas. A estos rasgos se sumarán la dulzura y maternalidad de 
Juanita Lepilaf, el humor y la frescura de las mujeres de Labranza, el canto de Carmela y sus saberes. Pero lo que más le impresionará, dejando en ella una profunda huella, será la fuerza y estatura de la machi María Painen Cotaro. A través de todas estas mujeres, ella recupera la imagen de un sujeto femenino conflictuado por las injusticias sociales y de género, pero portadora de un mundo propio, representado por el amor a las tareas domésticas, medicinales y maternales. Ya en "La jardinera", tonada compuesta en 1956, Violeta había anticipado la imagen de estas mujeres fuertes de la cultura chilena. La jardinera encuentra consuelo en las faenas hortícolas, y luego, una nueva vida en un jardín hecho de flores y hierbas. Fuerza que es tan grande, que incluso alcanza para curar al propio "traidor". En esta canción la mujer se vuelve más segura y la traición amorosa puede ser superada por esta huertera trabajadora, capaz de autocurarse: "Por suerte que tengo la buena costumbre de curar yo misma mis heridas", le dice en una carta a Gilbert Favré (PARRA. I, 2009: p. 188). En ese gesto Violeta se entronca con la imagen de mujeres capaces de cambiar, reinventar el mundo y superar la muerte, debido justamente al paralelismo entre la imagen femenina y la madre tierra. Sanadoras mestizas, machi y cantoras de tonadas, se amalgaman así formando un solo modelo. Hay también devoción por la figura de la madre (al igual que en la cultura mapuche) y formas matrilineales de organización del hogar y de trasmisión del saber. En definitiva, un saber que surge del sentir haciendo: "Lo que puede el sentimiento/ no lo ha podido el saber" (PARRA. V, 2016: p. 48), dirá más tarde.

\section{4-. Impacto en su obra de creación}

El impacto en su obra de creación, podría pensarse en al menos cinco sentidos, todos convergentes e influidos en diversos grados por su investigación en Lautaro, Millelche y Labranza. El primero, es la transfiguración que se produce en ella al conocer el mundo de María Painen Cotaro y que impactará fuertemente en su etapa de eclosión creativa y gran experimentación, a partir de 1957, siendo la composición de "El Gavilán" y de sus décimas autobiográficas el gesto más radical de esta transformación. El segundo, pertenece a la etapa más de crítica social de su obra (1960-1964), y se verifica en un sentido reivindicacionista y compasivo. El tercer sentido, estará dado por sus canciones vitalistas y de vínculo profundo con la naturaleza. Un cuarto sentido, registra metafóricamente la imagen de un Sur de Chile "indigenizando" el norte y, por último; la asimilación que ella logra del carácter ritual del canto, expresado obviamente en "El Guillatún" de 1966, pero también en "Gracias a la vida", la canción que mis amigos pehuenche, Gerónimo Nahuelcura y Olga Domihual, consideran su canto más mapuche.

\subsection{1-. Amores y dolores en "El Gavilán" y en "Qué he sacado con quererte"}

Cuando Violeta le pide al ülkantufe Juan López que le cante una canción y él titubea, entre ambos concluyen que esa canción tiene que ser de amor: "De amor tiene que ser, pueh" (MIRANDA, 2017: p.70), le dice Violeta. Amor doliente, catarsis amorosa, amor lúdico, cantos de seducción, éticas del amor, amor entre hermanas, amigas y primas, concepciones del amor entrelazadas a hierbas, pájaros o musgos. En el territorio del amor, en esos "jardines humanos" (PARRA.V, 2016: p. 63), será donde ella propondrá nuevas maneras de decir el amor: en "El Gavilán" de 1957 o en "Maldigo del alto cielo" de 1966, bajo imágenes y pulsiones tanáticas y destructivas, será posible realizar la catarsis del dolor amoroso; pero propondrá también nuevas éticas y posibilidades para la 
convivencia humana. Cantos rituales de gratitud e iniciación ${ }^{15}$ es lo que hay en Las últimas composiciones (1966).

Punto aparte merece el impacto que va a provocar este contacto en "El Gavilán" de 1957, y que la investigadora Lucy Oporto había vinculado en su libro de 2013 tan lúcidamente a la imagen de la machi ${ }^{16}$ (OPORTO, 2013: p.183). La potencia de ciertos ritmos, el quiebre de la sonoridad y la fuerza de los instrumentos, replicarían, según Oporto, los mecanismos que utiliza la machi para inducir el trance y comunicarse con el mundo de los espíritus, especialmente en su papel de sanadora. De entre las influencias que la convivencia con las y el ülkantufe pudo haber tenido, destaco solo una: el trabajo con la voz y la emoción. Violeta ha escuchado y grabado durante varios meses sus voces y todas ellas trasuntan una enorme emotividad, inflexiones de sufrimiento y sentimentalidad, pero sin jamás caer en tonos melodramáticos. A veces el ül se transforma en un suspiro, en un quejido o lamento, en una oración. Esa sonoridad sin duda ha quedado registrada en la voz que está detrás de "El Gavilán" y que la misma Violeta imaginó en ese registro. Esa voz y sus quiebres será la que permitirá que el canto pueda ser una vía de purificación y sanación frente a la muerte por asesinato, de la que será víctima la gallina.

Otra canción amorosa en esta línea es "Qué he sacado con quererte" de 1965, aunque en un recital en Ginebra ese mismo año, ella indicase que se llamaba "Ayayay". Para Enrique Bello la canción "suena a antigua queja india" (BELLO, 1965: s/p) ${ }^{17}$. En la melodía y en el sentido fundamental de la palabra, resuena cierto lamento presente en varios de los cantos recopilados. El lamento se acentúa al final de cada verso, con el "ay" y al final de cada estrofa con el "iayayay, ay, ay! (PARRA.V, 2016: p.79) Cada momento de la canción define su sentido por esta queja, la que irá in crescendo, especialmente en la primera versión de la canción, en la que hacia el final, registra no solo la voz de Violeta y su suspiro, sino también una especie de llanto breve. Ella captó esta "pena" profunda en la interpretación de los ül, especialmente los que le compartieron las cantoras Carmela Colipi (canto de viuda y por la hija fallecida), María ("Me abandonaste") y Rosita ("Me dijiste que no me mentirías"). Ellas le trasmiten ese hondo pesar, que atraviesa su propio lamento en "Qué he sacado con quererte" de 1963. En esta canción, la belleza y armonía de la naturaleza, se contradice con la maldad que representa aquel que ha abandonado a la mujer: "Pero tú, palomo ingrato/ ya no arrullas en mi nido" (PARRA.V, 2016:p74) Al igual que en "El Gavilán", las mujeres valoran las virtudes de aquel que han amado, aunque muy pronto admiten su imperfección y crueldad, y optan por un dolor que será purificado a través del canto y el suspiro: “¡Ayayay, ay, ay, ay!” (PARRA.V, 2016:p79). Ese lamento está también muy presente en otra canción grabada en la misma época en París, "Santiago, penando estás", pero ahora ampliando el sentimiento del abandono y la traición hacia toda una sociedad: la de una ciudad de Santiago sometida a las injusticias sociales y a los gobierno opresores del siglo XX.

\subsection{2-. Reinvindicación derrotista y compasiva}

En la línea reinvindicacionista, hay dos cantos fundamentales: "Levántate, Huenchullán", editada también como "Arauco tiene una pena" en 1962 y "Según el favor del viento", del mismo año. En la primera, en clave derrotista y a la vez reivindicacionista, se afronta el despojo y usurpación de los que ha sido víctima el pueblo mapuche desde la conquista y colonización hasta el presente. Se hace además una fuerte crítica a cómo las instituciones chilenas actuales, continúan con esta triste historia de sometimiento. La canción tiene un ritmo de refalosa "chicoteada", pero no connota el baile chileno-argentino del siglo XIX 
en ningún sentido. Aquí se consigna el calvario inevitable que ha debido y que deberá padecer el mapuche. El último verso de cada estrofa remata con el llamado a un levantamiento indígena en la persona de diversos longkos de la comunidad, pero lejos de remitir a una proclama de alzamiento indígena, esto es el suspiro final de quien ha caído en la desesperanza más absoluta e irreversible: "totora de cinco siglos, nunca se habrá de secar" (PARRA.V, 2016: p.121). Llama la atención que los diversos apellidos invocados, remitan efectivamente a líderes cuyos descendientes Violeta conoció en su trabajo de recopilación (Quilapan, Manquilef, por ejemplo) y que todos sean caciques y longkos que combatieron en la guerra mapuche contra la ocupación española. Cada uno de ellos obtuvo triunfos parciales sobre los usurpadores, pero también de manera cíclica, todos ellos fueron cruelmente asesinados: es el caso de Galvarino, Lautaro, Quilapan y Caupolicán.

Esta visión derrotista está aplacada en una tercera versión de esta canción. En dos estrofas agregadas, Violeta se vincula afirmativamente y en el presente con los sentidos de la cultura mapuche, desde su cosmovisión y desde su especial vínculo con la naturaleza. Esta tercera versión resulta ser muy importante, porque es la única vez que Violeta, en su obra, nombra esta cultura como la "mapuche": "porque al mapuche le clavan/ el centro del corazón” (PARRA.V, 2016: p.122). Además, en esta versión Violeta volvió a cambiar los nombres de algunos de los longkos o héroes emancipadores (ya lo había hecho en la versión de 1963), y agregó una estrofa final de diverso registro a todas las anteriores, en clave más eco-poética que histórica. En ella, hay una queja porque las especies arbóreas nativas ya no darán sus frutos, pues aparecen secándose y en abierto peligro de extinción. Si el levantamiento no tiene posibilidad aquí, tampoco tendrán posibilidad de ser preservados los recursos naturales resguardados por los mapuche, adelantándose así a las crisis ecológicas, ambientales y económicas vinculadas hoy a las luchas por la recuperación de tierras de parte de los pueblos indígenas.

En esta misma línea reivindicacionista, pero bajo una escena más plástica está su "Según el favor del viento" de 1962. En esta canción, la favorita de Nicanor Parra, en una barquichuela en medio del mar tormentoso de Chiloé, tienen lugar las penurias que debe sufrir el isleño que atraviesa las inclemencias del clima marino y las injusticias sociales, para llegar con mucho sacrificio hasta el puerto y vender allí su leña, recibiendo a cambio solo más miseria y padecimiento. El isleño intentará en Castro vender la leña de pellín que ha traído desde el monte (dejando atrás sus "rucas"): "Con su carguita de leña/ que viene a vender al puerto/ compra un kilo azúcar/ para endulzar sus tormentos" (PARRA.V, 2016: p.99). La extrema dureza de las condiciones en que trabajan los indígenas, la humildad sacrificial de sus labores y la adversidad histórica y geológica (el mar inclemente), quedan en parte atenuadas gracias a algunas imágenes cálidas y acogedoras. Ahí, en esa precaria balsa hecha de frío y tormentas/os, existen también imágenes nutricias: las manos de la isleña pelan papas y anuncian con ello el "milcao" (pan de papa y harina) y el mate: "en un rincón de la barca está hirviendo la tetera" (PARRA.V, 2016: p.98), lo que prepara la escena de la siguiente estrofa: "Chupando su matecito/ o bien su pescado seco/ acurrucado en su lancha/ va meditando el isleño" (PARRA.V, 2016: p.99). Los "tormentos" son endulzados por pequeños destellos de protección que iluminan humanamente las escenas, con efectos de compasión y calidez. Esta sensación que la canción trasmite de cierta protección e infinita ternura, está dada también por la actitud solidaria de quien testimonia todo esto, cerrándose cada estrofa con un ritualístico mantra, de lamento y de autoexigencia: "llorando estoy, /...según el 
favor del viento/ me voy me voy" (PARRA.V, 2016: p.101). Ese yo realiza además dos acciones más de liberación y compasión: la que denuncia deseará morir por los isleños en el canto - "Quisiera morir cantando/ sobre de un barco leñero" (PARRA.V, 2016: p.100).Forma de morir, que remite al mundo mapuche, que en su wampu (canoa) y cantando, anhela partir al otro mundo, según me indica Elisa Loncon. Como cierre liberador, recurrirá Violeta a una segunda acción, bajo una religiosidad ligada al canto a lo divino y a la teología de la liberación: "Y venga el trueno furioso/ con el clarín de San Pedro/ Llorando estoy/y barra los ministerios, me voy me voy" (PARRA.V, 2016: p.100).

Como complemento y proyección de todo esto, habrá dos piezas musicales más, editadas en 1966 en Chile, ambas instrumentales que también recogen esta nueva influencia mapuche: "Tocata y fuga (o Los mapuches)", grabada a mediados de 1965 y editada en 1966 en un single de Emi Odeon; y "Galambito Temucano (galambo, danza del sur de Chile), del mismo año, pieza interpretada por Violeta y Gilbert Favré.

\subsection{3-. Rituales de gratitud y petición}

Pero al igual que en la cultura mapuche, donde la vida tiene siempre una dimensión dual, la barca de sufrimiento a la intemperie de "Según el favor del viento" de 1962, se transformará en una barca prodigiosa y mágica en su canción "Es una barca de amores" ( Canciones reencontradas en París, 1971), grabada en París en 1963. Esta canción inaugura una compenetración más plena con la cultura mapuche, saliéndose del tono reinvindicacionista y entrando de lleno en la cultura mapuche vista desde dentro y en sintonía con sus propias visiones y valoraciones del mundo. Esta canción se centra en la intensidad del sentimiento amoroso que podrá unir y reconciliar, bajo la "flor del comprendimiento" (PARRA.V, 2016: p.63), a todos los pueblos del mundo, entendidos como "jardines humanos". En esta canción, que además evidencia en su estribillo una clara influencia musical mapuche, una barca universal navega lúdicamente los mares, llevando amor y luz a todos los rincones y puertos. La visión es cíclica, de transformación, cambio y vitalismo, basada en las dinámicas de la naturaleza, la que es concebida como un ser vivo. La breve canción está hecha de potentes y a la vez delicadas imágenes que entrelazan la belleza de la naturaleza con el comportamiento humano. El ser humano es visto aquí en su condición positiva y afirmativa, siguiendo los ciclos y dinámicas de la naturaleza: "En los jardines humanos/ que alumbran toda la tierra" (PARRA.V, 2016: p.63). La última estrofa remitirá a la importancia de la amistad filial y pasional, analogada nuevamente con la madre tierra: "el árbol más amistoso/ y el fruto de la pasión" (PARRA.V, 2016: p.63), remarcando con esto el tema central de su canción "Volver a los 17" de 1966, ese que superpone la superioridad de la emoción amorosa a cualquier tipo de saber o acción: "Lo que puede el sentimiento/ no lo ha podido el saber/ ni el más claro proceder/ ni el más ancho penamiento" (PARRA.V, 2016: p.48).

Pero será claramente en "El Guillatún" de 1966 donde la compositora desplegará todo lo que llegó a compenetrarse y enamorarse de esos treinta y nueve ül mapuche. Para José Pérez de Arce, el "guillatun es el espacio en el que el pueblo mapuche elabora su arte musical mayor" (HORMAZÁBAL, 2013: p.148). Es probable que Violeta Parra haya asistido en Millelche a ceremonias de sanación (machitún) y rogativa (ngillatun), por lo que le es posible describir con mucha precisión y conocimiento en qué consiste la rogativa. En la descripción de la ceremonia, que se desarrolla a medida que la canción avanza, interviene activamente toda la gente de la comunidad, comenzando por la machi, a la que se suma gente que ha sido sanada por ella ("hasta los enfermos de su machitún") para abarcar 
finalmente a toda la comunidad de Millelche: "los indios resuelven", "aumentan las filas", "se juntan los indios en un corralón" (PARRA.V, 2016: p.119). El protagonista de la ceremonia descrita será finalmente toda la comunidad de Millelche, y el canto que aquí se reivindica será el de todos, los gritos colectivos expresados en el afafán serán de gran relevancia, pues con ellos adquiere fuerza, apoyo y sentido la ceremonia total. Las fuerzas divinas han escuchado a la comunidad y finalmente "El rey de los cielos muy bien escuchó/ remonta los vientos para otra región" (PARRA.V, 2016: p.119). La transfiguración de la realidad se ha producido gracias a la fuerza colectiva del ngillatun, el que cerrará el círculo ritual ofrendado a esos mismos dioses.

En este canto presenciaremos el desarrollo del ritual mapuche por medio del cual se realiza una rogativa para pedir que "cesen" las lluvias, casi como si estuviésemos asistiendo vivencialmente a la rogativa. La melodía es una "danza al estilo araucano", de una monotonía intensificadora y de purificación. Parte del último verso se repite dos veces, llevando el canto hacia la reiteración, el mantra y la oralidad. En el transcurso del canto, se describe la realización del ritual sincrético en que participa toda la comunidad comandada por la machi y donde se le pedirá a "Isidro", "Dios" y "San Juan" (PARRA.V, 2016: p.119), así nombrados, por el término del temporal que está provocando la pérdida de las cosechas. El canto y los instrumentos de la comunidad, sumados a la invocación solar hecha por la machi, permiten el milagro:

El rey de los cielos muy bien escuchó remonta los vientos para otra región, deshizo las nubes después se acostó, los indios le cubren con una oración con una oración, con una oración.

(PARRA, V. 2016: p.119).

Producida la acción tendrá lugar el ofrecimiento a Dios del "primer almud" (PARRA.V, 2016: p.120) y la fiesta de la cosecha, luego de la cual volverán los "indios" a guardar: "el canto, el baile y el pan" (PARRA.V, 2016: p.120). El cumplimiento del ritual gracias a la rogativa, el agradecimiento indígena, la renovación del ciclo agrícola, el gesto de "guardar" que implica que eso volverá a ser usado próximamente y que por el momento se deja a resguardo, tiene otro sentido muy distinto al de la queja de "Levántate, Huenchullán" de 1962. Esta mirada se inscribe en la lógica de la plena vigencia de las culturas indígenas, que tiene que ver ya no con los indigenismos integracionistas y desarrollistas, sino con la "autonomía" y la "autodeterminación" de esos pueblos, que han conservado y renovado su caudal de conocimiento y tradiciones, y que gracias a ellas podrán seguir sobreviviendo.

\subsection{4-. Ritualidad mapuche: "Gracias a la vida”}

40 Ya he comentado cómo para mis amigos pehuenche la canción "más mapuche" sería "Gracias a la vida" de 1966. Pues según ellos, esta canción cumpliría exactamente las mismas funciones que cumplían sus cantos del ngillatun: agradecer por todo lo que recibimos diariamente.

41 Hay muchos elementos en ella que le vienen dados justamente de la concepción poética del canto mapuche: su ritualidad, su ética del amor, su función social. Ella representa junto con "Volver a los 17", del mismo disco, la sublimación positiva del amor, con una fuerte presencia del sentido de vitalismo y regeneración, poetizados bajo la fórmula y el acto del agradecimiento. Cada estrofa ofrece un cuadro autónomo de la gratitud, que se 
compone de tres gestos: el de agradecer, la obtención del don (la gracia) y la proyección plena de éste en el sujeto amado. La canción es un acto verbal de agradecimiento hacia la vida y hacia todo lo que ella permite: la visión, la audición, el sonido de las palabras, la marcha, la pasión, la risa y el llanto. Todas esas dádivas existenciales le permiten al yo mirar y sentir el mundo transmutado en belleza estética, en percepción humanizante; aunque el objetivo pleno se logre solamente en la posibilidad de poseer, a través de esos dones, al amado. Aquí las relaciones implican complementariedad y reconocimiento del otro.

Por eso "Gracias a la vida" es mucho más que una canción, es un acto ritual de gratitud y sanación, es una palabra-acción que permite, en distintas circunstancias vitales, expresar la gratitud y la posibilidad de que la vida continúe, pese a todo. Solo habría que agregar que la capacidad de agradecer por lo que se ha obtenido, es más común entre las cosmovisiones campesinas e indígenas que entre las occidentales. Según los abuelos maya-quichés Nan Faviana Cochoy y Tat Pedro Celestino Yac Noj, un principio básico para vivir mejor es agradecer, pues en ese gesto, lo que cada uno ha recibido como don o dádiva, no queda encerrado en uno mismo, sino que se refleja hacia aquel o aquello que lo ha posibilitado y así la buena energía circulará permanentemente entre los que dan y los que reciben, promoviéndose relaciones de reciprocidad y de cooperación genuinas. Agradecimiento, respeto y reciprocidad son la base para una convivencia plena en comunidad. De ahí que esta canción se deba imaginar más bien como una ética de comportamiento, como una ecopoética, que ha encontrado en el canto ritual mapuche su sentido fundamental y definitivo, su forma de agradecer a la vida: "Y el canto de todos/ que es mi propio canto" (PARRA.V, 2016: p.143).

Todo este trabajo impactará en toda su creación, y no solo en las canciones más explícitamente vinculadas con lo indígena, como "Levántate, Huenchullán", "El Guillatún" o "Según el favor del viento". Todos estos cantos tienden a las analogías, a un vínculo con los sonidos y sensaciones ligadas a la naturaleza: "Para olvidarme de ti voy a cultivar la tierra" (PARRA.V, 2016: p.64), había dicho ya antes en "La jardinera". Pero hay también en esta palabra indígena una responsabilidad social: la transmisión de una ética de comportamiento que deberán asumir tanto emisores como receptores y que, en Violeta Parra, se verifica como una aspiración a la verdad, esa que según sus propias palabras "anda a la sombra en la tierra" (PARRA.V, 1970:p.158). Muy parecido al concepto mapuche de la koybatun (mentira) que debe ser desterrada. Esa realización permite a las comunidades hacer catarsis, sanaciones, rituales conmemorativos o chamánicos, actos cotidianos de reafirmación identitaria y acciones que los ayudan a superar la "avería de lo cotidiano", para decirlo con palabras de Jorge Teillier. Pero sobre todo, su canto se transformará en puente entre culturas y en nuevos desafíos para el encuentro intercultural.

Este trabajo se ha realizado en el marco del Proyecto Fondap-CONICYT No 1510006 “Creación y consolidación del Centro de Estudios Interculturales e Indígenas (CIIR), del que Paula Miranda es Investigadora Asociada. 


\section{BIBLIOGRAFÍA}

ARGUEDAS, José María (1968), "Análisis de un genio popular hacen artistas y escritores", en Revista de Educación № 13, Santiago de Chile.

BENGOA, José (2000), Historia del pueblo mapuche (siglo XIX y XX), Lom Ediciones, Santiago de Chile.

BOCCARA, Guillaume (2012), “La interculturalidad como campo social”, en Cuadernos interculturales $\mathrm{N}^{\circ} 18$, Revista de Universidad de Playa Ancha, Viña del Mar. Disponible en https:// www.redalyc.org/pdf/552/55223841002.pdf.

CÁDIZ, Francisco (2013), “La 'chilenización' en el Norte y Sur de Chile: Una necesaria revisión”, en Cuadernos Interculturales $\mathrm{N}^{\circ}$ 2, Revista de Universidad de Playa Ancha, Viña del Mar. Disponible en https://www.redalyc.org/pdf/552/55228138002.pdf.

CHIHUAILAF, Elicura (1999), Recado confidencial a los chilenos, LOM Ediciones, Santiago de Chile.

GONZÁLEZ, Sergio (1995), “El poder del símbolo en la chilenización de Tarapacá”, en Revista de Ciencias Sociales $\mathrm{N}^{\circ} 5$, Revista de Universidad Arturo Prat, Tarapacá. Disponible en https:// www.redalyc.org/pdf/708/70800503.pdf.

GONZÁLEZ, Sergio (2002), Chilenizando a Tunupa: La escuela pública en el Tarapacá andino 1880-1990, DIBAM, Santiago de Chile.

HORMAZÁBAL, Viviana (2013), “La obra visual de Violeta Parra: un acercamiento a sus innovaciones conceptuales y visuales a través del análisis inconográfico de arpilleras y óleo", Tesis de Licenciatura en Artes, Universidad de Chile.

MARIMÁN, Pablo (2006), “Los mapuches antes de la conquista militar chilenoargentina”, j... Escucha, winka...! Cuatro ensayos de Historia Nacional Mapuche y un epilogo sobre el futuro, Lom Ediciones, Santiago de Chile.

MIRANDA, Paula (2013), “Poesía amorosa: enamoramientos, gratitudes y maledicencias”, La poesía de Violeta Parra, Editorial Cuarto Propio, Santiago de Chile.

MIRANDA, Paula, LONCON Elisa y Allison RAMAY (2017), Violeta Parra en el Wallmapu. Su encuentro con el canto mapuche, Pehuén, Santiago de Chile.

OPORTO, Lucy (2013), “Análisis de la estructura formal: una carnicería afectiva”, en El Diablo en la música. La muerte del amor en "El Gavilán", de Violeta Parra, Editoral USACH, Santiago de Chile.

PALACIOS, Raúl (1974). La chilenización de Tacna y Arica 188-1929, Editorial Jurídica, Lima

PARRA, Ángel (2006), Violeta se fue a los cielos, Catalonia, Santiago de Chile.

PARRA, Isabel (2009), El libro mayor de Violeta Parra. Un relato biográfico y testimonial, Editorial

Cuarto Propio, Santiago de Chile.

PARRA, Nicanor (1969), Obra Gruesa, Editorial Universitaria, Santiago de Chile.

PARRA, Violeta (1956), Cantos de Chile, Le Chant du Monde, París.

PARRA, Violeta (1956), Chants et danses du Chili, vol.1, Le Chant du Monde, París.

PARRA, Violeta (1956), Chants et danses du Chili, vol.2, Le Chant du Monde, París.

PARRA, Violeta (1956), El folklore de Chile. Violeta Parra. Canto y guitarra, vol.1, Odeón. 
PARRA, Violeta (1958), Canto y guitarra. El folklore de Chile, vol.2, Odeón.

PARRA, Violeta (1958), Conversación. Carrete 096: Recolecciones de Violeta Parra en Temuco, Archivo de Música Tradicional Chilena de la Universidad de Chile, Santiago de Chile.

PARRA, Violeta (1959), La cueca presentada por Violeta Parra. El folklore de Chile, vol.3, Odeón.

PARRA, Violeta (1959), Tonadas. El folklore de Chile. La tonada presentada por Violeta Parra, vol.VI, Odeón.

PARRA, Violeta (1960), Toda Violeta Parra, El folklore de Chile, vol.VII, Odeón.

PARRA, Violeta (1962), El folklore de Chile según Violeta Parra, Odeón.

PARRA, Violeta (1965), Carátula. Recordando a Chile/ Violeta Parra (Una chilena en París), Odeon, Santiago de Chile.

PARRA, Violeta (1965), Poésie populaire des Andes, Maspero, París.

PARRA, Violeta (1966), Las últimas composiciones, RCA Victor, Santiago de Chile.

PARRA, Violeta (1970), Décimas. Autobiografía en versos chilenos, Ediciones Nueva Universidad, Santiago de Chile.

PARRA, Violeta (1979), Cantos folklóricos chilenos, Editorial Nascimiento, Santiago de Chile.

PARRA, Violeta (2010), Entrevista de Mario Céspedes en el Hotel Bío Bío en 1960, en Violeta Parra en el Aula Magna de Concepción, Fundación Violeta Parra y Sello Oveja Negra, Concepción.

PARRA, Violeta (2016), Violeta Parra Poesía, Editorial UV de la Universidad de Valparaíso, Valparaíso.

PINTO, Jorge (1998), “La Araucanía, 1750-1850. Un mundo fronterizo en Chile a fines de la Colonia y comienzos de la República", Modernización, Inmigración y Mundo Indígena Chile y la Araucanía en el siglo XIX, Ediciones de la Universidad de La Frontera, Temuco.

PINTO, Jorge (2001), De la inclusión a la exclusión: la formación del Estado, la nación y el pueblo mapuche , Universidad de Santiago-Instituto de Estudios Avanzados, Santiago de Chile.

PINTO, Jorge (2007), “Expansión económica y conflicto mapuche. La araucanía, 1900-1940”, en Revista de Historia Social y de las Mentalidades №11, Revista de la Universidad de Santiago, Santiago de Chile. Disponible en http://www.revistas.usach.cl/ojs/index.php/historiasocial/ article/view/208/195.

RENDÓN, Víctor (2000), “Introducción”, en Música tradicional chilena de los 50, Fondart Regional y Universidad de Chile, Santiago de Chile.

SUBERCASEUX, Bernardo, STAMBUCK Patricia y Jaime LONDOÑO (1982), Gracias a la vida. Violeta Parra Testimonio, Editora Granizo, Santiago de Chile.

TIMMERMANN, Freddy (2004), “Guerra, Política, Hegemonía, Poder. Mundo Mapuche, Siglos XVIII y XIX. Algunas Reflexiones”, en Revista de Historia y Geografía №18, Revista de la Universidad Católica Silva Henríquez, Santiago de Chile. Disponible en http:// bibliotecadigital.ucsh.cl:90/greenstone//collect/revista1/index/assoc/HASH8fca/f08cee9e.dir/ Guerra\%20politica.pdf. 


\section{NOTAS}

1. La expresión "chilenización" de suele aplicar a los procesos de "desperuanización" ocurridos en las ciudades de Tacna, Arica y Tarapacá, luego de la Guerra del Pacífico (Cf. Chilenizando a Tunupa.La escuela pública en el Tarapacá Andino 1880-1990 de Sergio González Miranda (2002) o del mismo autor (1995): "El poder del símbolo en la chilenización de Tarapacá", Revista de Ciencias Sociales $\mathrm{N}^{\circ}$ 5: 42-56. Una seria y documentada crítica a las formas de entender esta chilenización por parte de González, es abordada junto a otras dimensiones del tema, en el fundamental artículo "La 'chilenización' en el Norte y Sur de Chile: Una necesaria revisión”, Francisco Cádiz (2013), Cuadernos Interculturales $N^{\circ} 20: 11-43$. Ver también: Palacios, Raúl (1974). La chilenización de Tacna y Arica 188-1929, Editorial Jurídica, Lima. Importantes estudios sobre la relación del Estado chileno con el pueblo mapuche, se refieren también, directa o tangencialmente, a este mismo fenómeno: Pinto, Jorge (1998, 2001, 2007); Timmermann, Freddy (2004): Bengoa, José (2000); Mariman, Pablo (2006); entre otros.

2. En un crítico artículo sobre el tema, Boccara distingue dos momentos en el uso de la noción de "interculturalidad". Una que está vigente hasta antes de los años 90 , usada por diversos agentes como herramienta de descolonicación del saber y de las relaciones sociales: "militantes y profesionales autóctonos que la vinculan al ámbito de la autogestión y de la educación bilingüe y la usan para revalidar los conocimientos de las culturas indígenas", de claro perfil político y de descolonización material y simbólica; y otra, usada a partir de los años 90, en que el término se vacía de su carga crítica para a ser una herramienta conceptual central de las estrategias neoindigenistas del Estado, transformándose en política pública a partir de la Ley Indígena de 1993. Aquí, la interculturalidad "se encuentra así extraída de las luchas políticas anti-hegemónicas indígenas para ser importada en el ámbito de las políticas estatales" (BOCCARA, 2012: p.16).

3. Las cintas que contienen estas entrevistas junto al registro de los cantos son las 95, 96, 97 y 101 y se encuentran en la Mediateca de la Universidad de Chile. En adelante, cuando nos refiramos e incluyamos citas de este material, indicaremos el número de cinta en la que se incluye la entrevista.

4. Hemos decidido omitir la pluralización de la palabra mapuche con la "s" de la gramática castellana, recomendada por la Academia Chilena de la Lengua, y de todas las palabras del mapuzugun; para dar espacio de expresión a la lengua mapuche con su propia gramática, siguiendo la trayectoria que han asumido los defensores de la lengua mapuzugun en los últimos años, en la que no existe la pluralización de sustantivos, pues en dicha lengua, cuando ello es necesario, se recurre al uso de un numeral, se pluraliza el adjetivo o se utiliza el colectivizador "pu".

5. Expresión utilizada por Elicura Chihuailaf en varias entrevisas y que acuñó en Recado confidencial a los chilenos (1999).

6. Esto tiene gran importancia también para la memoria musical chilena, como una forma de contrarrestar la manera por momentos homogeneizante en que hemos pensado nuestro folklore, pues todavía se invisibiliza el papel de los indígenas y negros en los estudios musicales "de la zona central" (Rendón, 2000: p.10-11). Según el mismo autor, "habría que reconsiderar la presencia indígena, especialmente en las manifestaciones de cultura popular que persisten hasta hoy" (Rendón, 2000: p.10-11). Es interesante que también Pereira Salas resalte en su mapa de la etnomúsica esta influencia mapuche en la zona central de Chile; la que se complementa con la zona de los pueblos del norte (atacameños) y del sur (yaganes y kaweskar).

7. PARRA, VIOLETA. Conversación. Carrete 096: Recolecciones de Violeta Parra en Temuco. Archivo de Música Tradicional Chilena. Universidad de Chile, 1958. 
8. Este último dato es testimonio de su hija Isabel Parra y está consignado en El Libro mayor de Violeta Parra (2009). Los datos referidos a las otras dos universidades están ampliamente respaldados en todos los estudios sobre la vida y obra de Violeta.

9. Se le nombra así en el material de difusión de la IV Escuela Internacional de Verano de la Universidad de Concepción (enero de 1958). Allí Violeta ofreció un curso de cueca y guitarra. Pero su vínculo con la U. de Concepción tiene además otros hitos: en mayo de 1957 había ofrecido un recital en el Salón de Honor de dicha Universidad; en junio de 1958 actuó en la inauguración de la II Escuela de Invierno de la U. de Concepción en Chillán y el 5 de enero de 1960 ofreció una conferencia en la VI Escuela Internacional de Verano en la misma casa de estudios superiores.

10. Entrevista de Mario Céspedes en el Hotel Bío Bío en 1960. Recopilado en Violeta Parra en el Aula Magna de Concepción. Fundación Violeta Parra y Sello Oveja Negra, 2010.

11. Ibid.

12. Excepción hecha de la fundamental referencia realizada por Ángel Parra (2006) en su biografía Violeta se fue a los cielos, Catalonia, Santiago.

13. Según testimonios de diversas personas de Millelche y muy especialmente de Ricardo Herrera Rossat, hijo de Hernán Herrera. Entrevistas realizadas por Paula Miranda entre 2015 y 2016.

14. Proyecto que consistió en la producción de una espacio cultural en la Comuna de La Reina, en Santiago de Chile, entre diciembre de 1965 y febrero de 1967.

15. Consultar Miranda, Paula. "Poesía amorosa: enamoramientos, gratitudes y maledicencias". La poesía de Violeta Parra. pp. 113-164. Editorial Cuarto Propio, 2013.

16. Capítulo 6 "Análisis de la estructura formal: una carnicería afectiva". pp. 175-184; solo presente en la edición de 2013 de El Diablo en la música. La muerte del amor en "El Gavilán", de Violeta Parra. Editoral USACH, (2º edición).

17. Contracarátula. Recordando a Chile/ Violeta Parra (Una Chilena en París). Odeon, 1965.

\section{RESÚMENES}

Este artículo explica y analiza las formas en que Violeta Parra (1917-1967), desde su arte y sus proyectos, propuso formas alternativas para el diálogo intercultural y para la reinvidicación y difusión de los saberes que la modernidad en el Chile del siglo XX, ha vuelto subalternos. Se analizan las formas atípicas en que llevó a cabo su trabajo de recopilación de las tradiciones poético-musicales del folklore y de la cultura popular chilena. En esta línea se describe en particular y pormenorizadamente su inmersión y trabajo pionero con la cultura mapuche (pueblo originario màs importante de (hile) a fines de los años 50, en base al hallazgo de cuatro cintas en que la compositora entrevista a un cantor y a seis cantoras mapuche y que no habían sido consideradas en ningún trabajo anterior sobre la autora. Se evidencia además, el impacto que tuvo este encuentro en su propia obra y el aporte determinante que significa la obra y proyectos de Violeta Parra para el diálogo intercultural desde posturas alternativas.

L'article explique et analyse comment Violeta Parra (1917-1967), à partir de son art et de ses projets culturels, a créé des formes alternatives pour un dialogue interculturel, à travers la revendication et la diffusion des savoirs subalternes dans le Chili du 20e siècle. On analyse ici la façon atypique dans laquelle elle a mené son travail de recueil des traditions poétiques musicales du folklore et de la culture populaire chiliens. Dans cette perspective, on décrit en détail son 
travail pionnier de la fin des années 50 sur la culture mapuche (le peuple natif plus important au Chili). Perspective ouverte par la découverte de quatre enregistrements de l'artiste avec interviews à un chanteur et six chanteuses mapuches. C'est un matériel absolutement inédit de la littérature de Violeta Parra. Il est aussi possible de mesurer l'impact de cette rencontre pour son propre travail, et l'apport déterminant que l'œuvre et les projets de l'artiste nous ont laissé pour un dialogue interculturel à partir de visions alternatives.

\section{ÍNDICE}

Mots-clés: Chant mapuche, Interculturalité, Projet culturel, Violeta Parra

Palabras claves: Canto mapuche Interculturalidad Proyecto cultural Violeta Parra

\section{AUTOR}

\section{PROF. PAULA MIRANDA HERRERA.}

Académica Asociada. Facultad de Letras. Pontificia Universidad Católica de Chile. paulamirandah (at)gmail.com 